\title{
PATRYCJA KOWALCZYK-RÓLCZYŃSKA
}

\section{Determinanty rozwoju odwróconego kredytu hipotecznego na rynku polskim}

Rozwój odwróconego kredytu hipotecznego na rynku polskim jest uwarunkowany wieloma czynnikami, które w literaturze przedmiotu z reguły dzieli się na demograficzne, ekonomiczne i społeczne. Jednak wśród nich znajduja się zarówno czynniki, które powinny pozytywnie wpływać na rozwój tego produktu, jak i czynniki, których oddziaływanie jest negatywne. Wniniejszym artykule podjęto próbę sklasyfikowania determinant rozwoju odwróconego kredytu hipotecznego przez pryzmat ich funkcji - hamujacej lub stymulujacej rozwój. Pozwoliło to na wyodrębnienie tych determinant, które stanowiq szczególnie ważnq barierę w wykreowaniu tego produktu na rynku polskim.

Słowa kluczowe: equity release, odwrócony kredyt hipoteczny, determinanty rozwoju, rynek polski.

\section{Wprowadzenie}

Odwrócony kredyt hipoteczny jest jednym z dwóch rodzajów usług typu equity release ${ }^{1}$, dzięki którym kapitał zgromadzony w nieruchomości zostaje przekształcony w płynne środki finansowe. Jest on produktem² ${ }^{2}$ skierowanym do osób starszych i może stanowić dodatkowe źródło uposażenia emerytalnego. Według regulacji obowiązujących na rynku polskim ${ }^{3}$, osoby, które chciałyby

1. Aby usługa mogła być zakwalifikowana jako usługa typu equity release, musi spełniać cztery podstawowe warunki. Po pierwsze, musi być usługą finansowa, po drugie, musi zapewniać źródło płynności na przyszłość, po trzecie - gwarantować dożywotnie prawo zamieszkiwania w nieruchomości i po czwarte - opierać spłatę wyłącznie o wartość nieruchomości (Ministerstwo Finansów, Założenia do projektu ustawy o odwróconym kredycie hipotecznym, 2011). Wyróżnia się dwie formy usług typu equity release: model sprzedażowy (sale model) oraz model kredytowy (loan model].

2. Literatura przedmiotu posługuje się określeniami: produkty equity release (m.in. J. Kłobukowska, Produkty equity release - szansa czy zagrożenie dla polskich seniorów?, „Pieniądze i Więź” 2013, vol. XVI, nr 1(58), s. 66-73) lub usługi equity release (m.in. M. Grzeszczuk-Gniewek, Odwrócony kredyt hipoteczny, „Państwo i Społeczeństwo" 2015, nr 2, s. 101-115).

3. Ustawa z dnia 23 października 2014 r. o odwróconym kredycie hipotecznym, Dz. U. 2014, poz. 1585. 
skorzystać z tego produktu, muszą posiadać prawo własności do nieruchomości lub musi im przysługiwać spółdzielcze własnościowe prawo do lokalu, na których może być ustanowione zabezpieczenie odwróconego kredytu hipotecznego. Wypłata z odwróconego kredytu hipotecznego może być dokonywana albo jednorazowo, albo w ratach wypłacanych przez określony w umowie okres. Na rynkach rozwiniętych funkcjonują także inne formy wypłat świadczeń z odwróconego kredytu hipotecznego, m.in. linia kredytowa, kombinacja linii kredytowej i płatności miesięcznych oraz miesięczne świadczenie pieniężne wypłacane tak długo, jak przynajmniej jeden z kredytobiorców będzie zamieszkiwał nieruchomość, która jest przedmiotem odwróconego kredytu hipotecznego ${ }^{4}$.

To, co różni dwa rodzaje usług typu equity release, to przede wszystkim moment przeniesienia własności nieruchomości. W przypadku odwróconego kredytu hipotecznego (który traktowany jest jako model kredytowy] przeniesienie prawa do nieruchomości na rzecz banku ${ }^{5}$ następuje po śmierci kredytobiorcy. Natomiast w przypadku drugiego rodzaju usługi - tzw. modelu sprzedażowego - przeniesienie własności nieruchomości na rzecz podmiotu oferujaccego taki produkt następuje w momencie podpisania umowy 6 . Model sprzedażowy oferowany jest na rynku polskim przez fundusze hipoteczne (m.in. Fundusz Hipoteczny DOM SA, Fundusz Hipoteczny Familia SA). W ramach tej usługi proponują one wypłatę renty dożywotniej, która podlega waloryzacji? Wartość wypłacanego świadczenia jest zależna od trzech czynników: wieku i płci świadczeniobiorcy oraz wartości nieruchomości ${ }^{8}$. Ponadto zaznaczyć należy, iż wartość wypłacanego świadczenia jest pomniejszana o wartość opłaty eksploatacyjnej (opłaty związanej z korzystaniem z nieruchomości) ${ }^{9}$. Z uwagi na fakt, iż przeniesienie wartości nieruchomości następuje w momencie zawarcia umowy, podmioty oferujące rentę dożywotnią ponoszą koszty związane z ubezpieczeniem nieruchomości od zdarzeń losowych oraz podatku od nieruchomości. Należy zaznaczyć, iż fundusze hipoteczne działające na rynku polskim funkcjonuja w oparciu o zapisy Kodeksu cywilnego ${ }^{10}$. Zauważono potrzebę bardziej rzetelnych uregulowań w tym zakresie, co spowodowało powstanie projektu ustawy o dożywotnim świadczeniu pieniężnym. Jednakże projekt ten, choć był już po konsultacjach społecznych i wszelkich uzgodnieniach, został wycofany ${ }^{11}$. Niezależnie od niewystarczających uwarunkowań prawnych obserwuje się zainteresowanie modelem sprzedażowym. W połowie 2015

4. Szerzej zob.: M. Nakajima, I.A.Telyukova, Reverse Mortgage Loans: A quantitative analysis, "Working Paper” 2013, no. 13-27, Research Department, Federal Reserve Bank Of Philadelphia, June 4; T.B. Bishop, H. Shan, Reverse Mortgages: A Closer Look at HECM Loans, 2008, http://www.nber.org/programs/ag/rrc/08-02\%20 Bishop,\%20Shan\%20FINAL.pdf [dostęp: 25.03.2017].

5. Na rynku polskim odwrócony kredyt hipoteczny może być oferowany przez banki oraz instytucje kredytowe.

6. Jednakże świadczeniobiorca ma prawo dożywotniego zamieszkania nieruchomości.

?. Fundusz Hipoteczny DOM SA waloryzuje wysokość świadczenia co kwartał, natomiast Fundusz Hipoteczny Familia SA raz w roku.

8. Fundusz Hipoteczny Familia SA wyznacza wartość renty dożywotniej w oparciu o wartość nieruchomości liczonej jako wartość dla wymuszonej sprzedaży, co oznacza, iż jest ona niższa niż rynkowa wartość nieruchomości.

9. Fundusz Hipoteczny DOM SA potrąca z wypłacanego świadczenia stałą wartość opłat eksploatacyjnych, przyjętą w momencie podpisywania umowy, i tym samym ponosi ryzyko wzrostu wartości tych opłat.

10. Fundusz Hipoteczny DOM SA zawiera umowy oparte o przepisy Kodeksu cywilnego dotyczące umowy renty oraz umowy o dożywocie. Umowa renty opisana jest w artykułach 903-907 k.c., a umowa o dożywocie w artykułach 908-916 k.c. Natomiast Fundusz Hipoteczny Familia SA wypłaca świadczenia renty dożywotniej w oparciu o artykuły 903-906 k.c. (Dz. U. 1964 nr 16 poz. 93).

11. Szczegóły: https://legislacja.rcl.gov.pl/projekt/227241/katalog/227249\#227249 [dostęp: 12.02.2018]. 
roku fundusze będące członkami Konferencji Przedsiębiorstw Finansowych w Polsce, których działalność obejmuje co najmniej 90\% rynku renty dożywotniej, administrowały 310 umowami oraz nieruchomościami o łącznej wartości 76,43 $\mathrm{mln} \mathbf{z}^{12}$.

Odwrócony kredyt hipoteczny podlega regulacjom prawnym na rynku polskim od niespełna trzech lat (ustawa o odwróconym kredycie hipotecznym ${ }^{13}$ weszła w życie 15 grudnia 2014 roku). Jednakże do dnia dzisiejszego żaden bank nie ma w swojej ofercie tego produktu. Z tego względu należy podjać dyskusję nad zarówno tymi czynnikami, które hamuja, jak i tymi, które powinny stymulować rozwój odwróconego kredytu hipotecznego w Polsce (a w zasadzie wprowadzenie tego produktu do oferty banków). Dlatego też identyfikacja, klasyfikacja (nieco inna niż dotychczas zaprezentowana w polskiej literaturze przedmiotu) oraz omówienie wspomnianych czynników są celami niniejszego artykułu.

Dodatkową motywacją do podjęcia dyskusji nad wspomnianymi czynnikami jest fakt, iż rok 2016 był rokiem przełomowym na rynku equity release w Wielkiej Brytanii - największego rynku tego typu usług w Europie. Łączna wartość zawartych umów wyniosła 2,15 mld GBP, co oznacza wzrost o 34\% w porównaniu z rokiem 2015, a liczba nowo zawartych umów przekroczyła 27,5 tys., co oznacza wzrost o $30 \%$ w stosunku do roku $2015^{14}$.

\section{Identyfikacja i klasyfikacja determinant warunkujących rozwój odwróconego kredytu hipotecznego}

Czynniki wpływające na rozwój odwróconego kredytu hipotecznego zostały już częściowo omówione w literaturze przedmiotu. Jerzy P. Gwizdała ${ }^{15}$ wskazuje, iż na powodzenie odwróconego kredytu hipotecznego na rynku polskim wpływ będzie miało wiele czynników demograficznych, ekonomicznych i społecznych. Z kolei lwa Kuchciak ${ }^{16}$ podkreśla, że poza czynnikami demograficznymi argumentem przemawiającym za wprowadzeniem odwróconego kredytu hipotecznego jest sytuacja na rynku nieruchomości mieszkaniowych (w szczególności tendencja wzrostowa cen). Anniek Joosten ${ }^{17}$ przedstawia natomiast różnego rodzaju ryzyka związane z produktami equity release, stanowiące jednocześnie barierę dla rozwoju tych produktów. W grupie rodzajów ryzyka towarzyszących odwróconemu kredytowi hipotecznemu wymienia ona: ryzyko polegające na tym, że suma wszystkich udzielonych odwróconych kredytów hipotecznych będzie większa niż łączna wartość nieruchomości stanowiących zabezpieczenie (tzw. cross-over risk), ryzyko ceny nieruchomości, ryzyko długowieczności, ryzyko stopy procentowej. Autorka wskazuje ponadto na inne

12. Szerzej: https://kpf.pl/renta-dozywotnia-produkt-sprawdzony-i-bezpieczny/ [dostęp: 10.05.2017].

13. Ustawa z dnia 23 października 2014 r. o odwróconym kredycie hipotecznym, Dz. U. 2014, poz. 1585.

14. Szerzej: Equity Release Market Report Spring 201?, s. 4, http://www.equityreleasecouncil.com/document-library/equity-release-market-report-spring-201?/ [dostęp: 04.03.2017].

15. J.P.Gwizdała, Wpływ czynników demograficzno-społecznych na rozwój odwróconego kredytu hipotecznego w Polsce, „Kwartalnik Kolegium Ekonomiczno-Społecznego Studia i Prace” 2015, nr 3, tom 2: Bankowość. Bankowość komercyjna i spółdzielcza, s. 177-192.

16. I. Kuchciak, Odwrócona hipoteka jako odpowiedź sektora bankowego na trendy demograficzne, „Annales Universitatis Mariae Curie-Skłodowska. Sectio H. Oeconomia" 2010, tom 44, nr 2, s. 297-309.

17. A. Joosten, Equity Release Products. Analysis for the Netherlands, „Netspar Academic Series” 2015, http:// arno.uvt.nl/show.cgi?fid=138960 [dostęp: 15.04.2017]. 
istotne bariery rynkowe, m.in. wiedzę finansową osób starszych, zaufanie do rynku finansowego, uwarunkowania kulturowe, uregulowania prawne. Z kolei Elsa Fornero, Maria Cristina Rossi i Maria Cesira Brancati ${ }^{18}$ omawiaja dość szczegółowo zagadnienia związane z rozwojem odwróconego kredytu hipotecznego, m.in. rodzaj gospodarstw domowych, które zainteresowane sạ tym produktem (single, wdowcy / wdowy), złą renomę wcześniejszej generacji produktów equity release, wysokie koszty związane z odwróconym kredytem hipotecznym oraz poziom konsumpcji w grupie osób starszych. Nad tą ostatnią kwestią pochylają się także Karen Gibler i Joseph Rabianski ${ }^{19}$ oraz Andrew Caplin ${ }^{20}$, który dodatkowo wskazuje, że problemy zdrowotne osób korzystajacych z odwróconego kredytu hipotecznego (np. zbyt długa hospitalizacja) moga przyczynić się do niewywiązania się przez nie z warunków umowy.

Warto dodać, iż rynek odwróconego kredytu hipotecznego jest także narażony na negatywna selekcję oraz hazard moralny². Realizacja tych zjawisk może być zagrożeniem albo dla banku, albo dla kredytobiorcy. Przykładem zagrożenia dla instytucji oferującej odwrócony kredyt hipoteczny może być sytuacja, w której kredytobiorca nie będzie zamierzał wykorzystać pozyskanych środków finansowych (np. w postaci jednorazowego świadczenia) do poprawy swojej sytuacji finansowej, tylko na przykład do sfinansowania potrzeb innych członków rodziny. W konsekwencji może to doprowadzić do braku wystarczających środków nie tylko na sfinansowanie bieżących potrzeb osoby starszej, ale także na utrzymanie nieruchomości w stanie niepogorszonym, na opłatę wymaganej składki ubezpieczeniowej, a w konsekwencji - do niewywiązania się z warunków umowy. Natomiast przykładem zagrożenia dla kredytobiorcy może być sytuacja, w której pracownik banku lub pośrednik finansowy oferujący odwrócony kredyt hipoteczny niedoinformuje go o różnych istotnych kwestiach związanych z tym produktem, a tym samym narazi go na przykład na dodatkowe koszty, lub co gorsza wypowiedzenie umowy 22 .

Wszystkie wskazane powyżej czynniki są bardzo istotne z punktu widzenia rozwoju odwróconego kredytu hipotecznego. Dlatego też zebrano je i podzielono ze względu na dwa kryteria: stymulowanie rozwoju odwróconego kredytu hipotecznego oraz hamowanie tego rozwoju (rys. 1.). W ramach takiego podziału można oczywiście pogrupować te czynniki na m.in. czynniki ekonomiczne, demograficzne, związane z rynkiem finansowym oraz rynkiem nieruchomości, społeczne, kulturowe.

18. E. Fornero, M.C. Rossi, M.C. Brancati, Explaining why, right or wrong, (Italian) households do not like reverse mortgages, „Journal of Pension Economics and Finance” 2016, 15, s. 180-202.

19. K. Gibler, J. Rabianski, Elderly Interest in Home Equity Conversion, „Housing Policy Debate” 1993, vol. 4, Issue 4.

20. A. Caplin, Inertia in the U.S. Housing Finance Market: Cases and Causes, Paper Prepared for the Joint AEA/ AREUEA Session, New York University, New Orleans 2000.

21. Szerzej zob.: H. Shan, Reversing the trend: the recent expansion of the reverse mortgage market, „Real Estate Economics" 2011, 39, s. 743-768.

22. Kwestia hazardu moralnego w działalności pośredników finansowych została omówiona w pracy A. Barembruch, Hazard moralny w działalności pośredników finansowych, „Prace i Materiały Wydziału Zarządzania Uniwersytetu Gdańskiego" 2011, nr 4/5, s. 293-302. 


\section{Rysunek 1. Klasyfikacja determinant warunkujących rozwój odwróconego kredytu hipotecznego}

\begin{tabular}{|c|c|c|}
\hline & & Niskie wartości emerytur z obowiązkowej (bazowej] części systemu emerytalnego \\
\hline & & Brak lub uboga oferta dodatkowych form zabezpieczenia emerytalnego \\
\hline & & Niski poziom oszczędności gospodarstw domowych \\
\hline & & Rosnąca liczba emerytów narażona na ryzyko ubóstwa \\
\hline & & Ujemne saldo migracji (głównie w grupie osób młodych) \\
\hline & & Wydłużające się trwanie życia (rosnąca liczba lat przebywania na emeryturze) \\
\hline & & Niska wartość współczynnika dzietności \\
\hline & $\begin{array}{l}\text { Determinanty } \\
\text { stymuluiace }\end{array}$ & $\begin{array}{l}\text { Stabilność cen na rynku nieruchomości mieszkaniowych (niskie ryzyko ceny } \\
\text { nieruchomości) }\end{array}$ \\
\hline & rozwój & Znaczący udział własności prywatnej nieruchomości \\
\hline & $\begin{array}{l}\text { kredytu } \\
\text { hipotecznego }\end{array}$ & $\begin{array}{l}\text { Zadawalajaca płynność na rynku nieruchomości mieszkaniowych (krótki okres } \\
\text { ekspozycji nieruchomości) }\end{array}$ \\
\hline & & $\begin{array}{l}\text { Zrozumiałe i przejrzyste uregulowania prawne dotyczące odwróconego kredytu } \\
\text { hipotecznego }\end{array}$ \\
\hline & & Współpraca banku z osobą starszą (kredytobiorca) przez cały okres kredytowania \\
\hline & & $\begin{array}{l}\text { Stabilność stóp procentowych wykorzystywanych do kalkulacji świadczeń } \\
\text { z odwróconego kredytu hipotecznego }\end{array}$ \\
\hline & & Stabilna sytuacja finansowa banków i instytucji kredytowych \\
\hline $\begin{array}{l}\text { Klasyfikacja } \\
\text { determinant } \\
\text { warunkujących }\end{array}$ & & $\begin{array}{l}\text { Zmiana mentalności polskiego społeczeństwa, w szczególności w grupie osób } \\
\text { starszych w kwestiach posiadania nieruchomości mieszkaniowych i przywiązania } \\
\text { do nich }\end{array}$ \\
\hline $\begin{array}{l}\text { odwróconego } \\
\text { kredytu }\end{array}$ & & $\begin{array}{l}\text { Intensywny rozwój zarówno obowiazkkowych, jak i dodatkowych form zabezpieczenia } \\
\text { emerytalnego }\end{array}$ \\
\hline mipotecznego & & Istotny wzrost stopy oszczędności gospodarstw domowych \\
\hline & & Realizacja ryzyka długowieczności \\
\hline & & Brak stosownych instrumentów służących do zarządzania ryzykiem długowieczności \\
\hline & & Wysokie ryzyko ceny nieruchomości \\
\hline & & Niska jakość wyceny nieruchomości mieszkaniowych \\
\hline & & Niekorzystne zmiany w polityce mieszkaniowej \\
\hline & hamujące & Niskie wartości świadczeń wypłacanych z odwróconego kredytu hipotecznego \\
\hline & rozwój & Wysokie koszty związane z zawarciem umowy odwróconego kredytu hipotecznego \\
\hline & kredytu & Zmienność stóp procentowych \\
\hline & nipotecznego & Problemy związane z płynnością/wypłacalnością banków \\
\hline & & Odległa perspektywa zysku (dla banku) \\
\hline & & $\begin{array}{l}\text { Niski stopień zaufania osób starszych do instytucji finansowych, niska jakość } \\
\text { obsługi osób starszych }\end{array}$ \\
\hline & & $\begin{array}{l}\text { Niezrozumiałe i zawiłe regulacje związane z zawarciem umowy odwróconego } \\
\text { kredytu hipotecznego }\end{array}$ \\
\hline & & $\begin{array}{l}\text { Brak postrzegania przez seniorów nieruchomości mieszkaniowej jako aktywa, które } \\
\text { może podlegać upłynnieniu w celu poprawy sytuacji finansowej }\end{array}$ \\
\hline & & Emocjonalne i psychologiczne przywiązanie do nieruchomości \\
\hline
\end{tabular}

Źródło: opracowanie własne. 


\section{Charakterystyka czynników stymulujących rozwój odwróconego kredytu hipotecznego}

Lista czynników, które powinny stymulować rozwój odwróconego kredytu hipotecznego w Polsce, jest dość długa. Istotną determinantą, którą należy omówić jest wysokość obecnych emerytur oraz ich wartości przyszłe, w znacznym stopniu mogace się przyczyniać do zainteresowania tym produktem. Według ZUS 23 na koniec marca 2017 roku przeciętna wysokość emerytury wyniosła: dla populacji mężczyzn - 2 582,96 zł, a dla populacji kobiet - 1 747,25 zł. Ponadto 75\% kobiet pobierało emeryturę w wysokości do 2045,91 zł, z czego 25\% kobiet pobierało świadczenie w wysokości do 1 268,13 zł. W przypadku mężczyzn sytuacja była zdecydowanie lepsza, bowiem $75 \%$ mężczyzn otrzymywało emeryturę w wysokości do 3 119,02 zł, z czego 25\% mężczyzn pobierało emeryturę w wysokości do 1 835,67 zł. Biorąc pod uwagę te informacje, można zauważyć, iż na rynku jest dość znaczny odsetek osób, głównie kobiet, których dochody są bardzo niskie i w przypadku których może zrealizować się ryzyko ubóstwa. Według danych Komisji Europejskiej ${ }^{24}$ zagrożonych ubóstwem i wykluczeniem społecznym na rynku polskim w 2015 roku było aż 17\% osób w grupie 65+. Im odsetek osób starszych narażonych na ryzyko ubóstwa będzie się zwiększał, tym bardziej intensywne powinny być poszukiwania źródeł dodatkowego dochodu. Ten dodatkowy dochód osób w wieku emerytalnym może pochodzić także z innych form zabezpieczenia emerytalnego (głównie dobrowolnych). W zależności od dostępności tych form zapotrzebowanie na odwrócony kredyt hipoteczny może się zmieniać. Jak wskazują dane UKNF, ${ }^{25}$ na koniec 2015 roku tylko niespełna 12\% ogółu liczby osób pracujących gromadziło oszczędności w ramach programów emerytalnych: IKE, IKZE oraz PPE. Natomiast na koniec 2016 roku łącznie 9,4\% ogółu osób pracujących posiadało IKE i / lub IKZE ${ }^{26}$.

Podejście do gromadzenia oszczędności w okresie aktywności zawodowej w celu zabezpieczenia starości jest bardzo ważnym aspektem zarządzania finansami gospodarstwa domowego. Jeżeli dochody gospodarstwa domowego w tym okresie były na tyle wysokie, aby gromadzić takie oszczędności, to w grupie tych osób raczej niewielu będzie zainteresowanych odwróconym kredytem hipotecznym. Natomiast brak zgromadzonych oszczędności lub ich niewielkie wartości moga sprzyjać podejmowaniu decyzji o skorzystaniu z odwróconego kredytu hipotecznego. Według danych NBP27 od połowy 2014 roku systematycznie obniżają się oszczędności dobrowolne gospodarstw domowych. Procesowi temu towarzyszy znacznie wolniejsze tempo wzrostu oszczędności emerytalnych w systemie kapitałowym. Ponadto - według badania przeprowadzonego przez TNS

23. ZUS, Departament Statystyki i Prognoz Aktuarialnych, Struktura wysokości emerytur i rent wypłacanych przez ZUS po waloryzacji i podwyższeniu świadczeń najniższych w marcu 2017 roku, Warszawa 2017, s. 19-20.

24. http://ec.europa.eu/eurostat/statistics-explained/index.php/People_at_risk_of_poverty_or_social_exclusion [dostęp: 10.04.2017].

25. UKNF (2016a), Indywidualne Konta Emerytalne oraz Indywidualne Konta Zabezpieczenia Emerytalnego w roku 2015, Warszawa 2016; UKNF (2016b), Informacja dotyczqca pracowniczych programów emerytalnych w 2015 r. https://www.knf.gov.pl/knf/pl/komponenty/img/informacja__PPE_w_2015_46129_56356.pdf [dostęp: 10.05.2017].

26. UKNF, Indywidualne Konta Emerytalne oraz Indywidualne Konta Zabezpieczenia Emerytalnego w 2016 roku, Warszawa 201 ?

27. NBP (2016a), Sytuacja finansowa sektora gospodarstw domowych w III kw. 2015 r., Warszawa 2016. 
Polska ${ }^{28}$ - 52\% polskiego społeczeństwa nie interesuje się produktami oszczędzania długoterminowego, natomiast spośród osób oszczędzających ponad jedna trzecia nie jest zainteresowana tymi produktami. Związane jest to głównie z brakiem stosownej wiedzy. Dlatego też istotna jest edukacja polskiego społeczeństwa w zakresie finansów.

Kolejnymi czynnikami stymulującymi rozwój odwróconego kredytu hipotecznego są zmiany demograficzne zachodzące na rynku polskim. Wyróżnić tutaj należy:

- Ujemne saldo migracji - głównie w grupie osób młodych, czyli tych które potencjalnie powinny odprowadzać składki w ramach bazowego systemu emerytalnego, co będzie przekładało się na dalsze niekorzystne zmiany w polskim systemie emerytalnym i ostatecznie na obniżenie świadczeń emerytalnych.

- Wydłużające się trwanie życia, a tym samym rosnąca liczbę lat przebywania na emeryturze. Według danych Komisji Europejskiej ${ }^{29}$ w 2013 roku średnie trwanie życia Polaka wynosiło 72,8 lat, a średnie trwanie życia Polki 80,9 lat. Natomiast w roku 2060 mają wynosić odpowiednio: 82,6 lat dla mężczyzn oraz 88,1 lat dla kobiet. Ta zmiana powodowała będzie, iż przy braku lub niewielkim wzroście wynagrodzeń ${ }^{30}$ w polskiej gospodarce wartości wypłacanych świadczeń emerytalnych z bazowej części systemu emerytalnego będą coraz niższe.

- Niską wartość współczynnika dzietności, a co za tym idzie zmiany w strukturze gospodarstw domowych. Rosnąca liczba gospodarstw domowych bez dzieci będzie powodowała, że nie będzie osób dziedziczących prawo do nieruchomości.

Kolejnymi determinantami mogacymi wpływać na zainteresowanie wprowadzeniem odwróconego kredytu hipotecznego na stałe do oferty banków i instytucji kredytowych są czynniki związane z rynkiem nieruchomości. Pierwszym, który należy wymienić, jest stabilność cen na rynku nieruchomości mieszkaniowych i - co z nią związane - niewielkie zagrożenie spadkiem rynkowej wartości nieruchomości. Biorąc pod uwagę fakt, iż banki dopiero rok po śmierci kredytobiorcy będa mogły sprzedać nieruchomość będącą zabezpieczeniem odwróconego kredytu hipotecznego, stabilność cen na rynku nieruchomości mieszkaniowych, a najlepiej ich wzrost, będą powodowały, że osiagnnięcie zysku z tego produktu będzie realne. Sprzyjać tutaj będzie także odpowiednia płynność na rynku nieruchomości. Im okres ekspozycji nieruchomości będzie krótszy, tym szybciej nastapi osiagnnięcie zysku.

Z ryzykiem utraty wartości nieruchomości związana jest nie tylko sytuacja na rynku nieruchomości mieszkaniowych, ale także odpowiednio prowadzona gospodarka remontowa nieruchomości stanowiącej zabezpieczenie odwróconego kredytu hipotecznego. W tym celu w wielu przypadkach jest konieczna współpraca banku z kredytobiorca (lub kredytobiorcami) przez cały okres obowiązywania umowy odwróconego kredytu hipotecznego. Warto tutaj wspomnieć, iż fundusze hipoteczne oferujące model sprzedażowy proponują (poza pakietami porad prawnych i pomocy medycznej) także usługi typu assistance home (z reguły odpłatnie), dzięki którym wartość nieruchomości wskutek jej użytkowania nie powinna spadać. Zasadnym byłoby także

28. TNS Polska, Oszczędzanie długoterminowe - opinie, postawy i oczekiwania polskiego społeczeństwa, 2014, https://zbp.pl/public/repozytorium/wydarzenia/images/listopad_2014/konferencja_prasowa/Raport_2014_11_ oszczedzanie_dlugoterminowe_pelny.pdf [dostęp: 08.06.2017].

29. Komisja Europejska, The 2015 Ageing Report, 2015.

30. Przy niezmiennej stopie składki na ubezpieczenie emerytalne. 
uruchomienie takiego wsparcia dla osób korzystających z odwróconego kredytu hipotecznego, w szczególności dla osób samotnych.

Kolejnymi determinantami stymulującymi rozwój omawianej usługi na rynku polskim są wszelkie czynniki związane z jego przejrzystością i zrozumiałymi uregulowaniami prawnymi. Dobrze sformułowane zasady korzystania z odwróconego kredytu hipotecznego, które będą chroniły interes zarówno banku, jak i kredytobiorcy, są wręcz pożądane. Poprawna konstrukcja tego produktu, brak ukrytych dodatkowych opłat, rzetelna i wyczerpująca informacja będą zachęcały osoby starsze do skorzystania z niego. Powiązane jest to z zaufaniem Polaków do banków i instytucji kredytujących (według Janusza Czapińskiego i Tomasza Panka ${ }^{31}$ w roku 2015 zaufanie do banków komercyjnych miało 44\% Polaków). Rosnąca liczba osób ufających bankom będzie sprzyjała rozwojowi nowych produktów bankowych.

Z zaufaniem do instytucji finansowych wiąże się stabilność systemu finansowego, a przede wszystkim stabilność sektora bankowego. Według raportu NBP32 (2016b) dotyczącego stabilności systemu finansowego sytuacja polskiego sektora bankowego jest oceniana dobrze ${ }^{33}$, co może tylko sprzyjać rozwojowi odwróconego kredytu hipotecznego. Gdyby ta stabilność była zachwiana, ani same banki nie byłby zainteresowane wprowadzeniem do oferty nowego, długoterminowego produktu, ani osoby starsze nie rozważałyby wykorzystania odwróconego kredytu hipotecznego do poprawy swojej sytuacji finansowej.

Ostatnią - niezwykle istotną - determinantą, jest zmiana mentalności polskiego społeczeństwa, głównie w grupie osób starszych, w kwestii posiadania nieruchomości mieszkaniowej i przywiązania do niej, jak również w kwestii chęci pozostawienia nieruchomości kolejnym pokoleniom. Wyparcie takiego spojrzenia oraz postrzeganie nieruchomości jako potencjalnego źródła dodatkowego dochodu pozwoli na rozwój odwróconego kredytu hipotecznego. To dodatkowe uposażenie emerytalne dla najuboższej grupy osób starszych może okazać się niezbędne do zaspokojenia podstawowych potrzeb i sfinansowania bieżącej konsumpcji. W przypadku osób pobierających wyższe świadczenia emerytalne z systemu bazowego środki finansowe z odwróconego kredytu hipotecznego pozwolą na poprawienie jakości życia oraz zaspokojenie potrzeb wyższego szczebla. Zaznaczyć warto, że na odstapienie od chęci pozostawienia nieruchomości kolejnym pokoleniom istotny wpływ mają relacje rodzinne. Przychylność dzieci czy wnuków do skorzystania przez osobę starszą z usługi equity release, a także ich pomoc przy zawieraniu umowy odwróconego kredytu hipotecznego sprzyjać będzie popytowi na te produkty.

31. J. Czapiński, T. Panek, Diagnoza społeczna 2015. Warunki i jakość życia Polaków, Rada Monitoringu Społecznego, Warszawa 2015.

32. NBP (2016b), Raport o stabilności systemu finansowego, Warszawa 2016, http://www.nbp.pl/systemfinansowy/rsf022016.pdf [dostęp: 10.06.2017].

33. Dobra kapitalizacja, wysoka płynność, zdywersyfikowanie źródeł finansowania i dobra sytuacja otoczenia makroekonomicznego przyczyniły się do podniesienia przez agencję Moody's do stabilnej perspektywy ratingu polskiego sektora bankowego we wrześniu 2015 roku. 


\section{Charakterystyka czynników hamujacych rozwój odwróconego kredytu hipotecznego}

Biorąc pod uwagę fakt, iż wprowadzanie odwróconego kredytu hipotecznego do oferty banków trwa już dość długo, należy podjać dyskusję nad czynnikami, które hamują rozwój tego produktu.

Pierwszą determinantą, którą mocno akcentuje UKNF, są aspekty praktyczne stosowania ustawy o odwróconym kredycie hipotecznym. Obowiązująca ustawa nie reguluje wszystkich kwestii i problemów związanych z funkcjonowaniem tego produktu, na przykład tego, kto i kiedy powinien poinformować bank o śmierci kredytobiorcy ${ }^{34}$. Na restrykcyjność niektórych zapisów w ustawie wskazuje także Tomasz Czech ${ }^{35}$, który podkreśla, iż stanowią one znaczącą barierę w rozwoju odwróconego kredytu hipotecznego na rynku polskim. Brak rozwiązań prawnych w istotnych dla banków kwestiach może powodować dalszą niechęć banków do oferowania tego produktu. Ponadto - z drugiej strony - niezrozumiałe i / lub nieprecyzyjne regulacje będą zniechęcały potencjalnych kredytobiorców. Brak dotarcia z informacją do strony popytowej lub dostarczenie tylko bardzo ogólnych informacji o produkcie nie zachęci osób starszych do skorzystania z niego. Jakość przekazu jest tutaj kolejnym bardzo istotnym elementem. Pożądane jest, aby osoby pracujące w banku prezentowały ten produkt w sposób odpowiedzialny i przejrzysty, nie stosowały niezrozumiałego dla osób starszych słownictwa i skrótów, chwytów w postaci „drobnego druku” czy utrudnień natury technologicznej ${ }^{36}$. Bez odpowiedzialnej i dobrej obsługi osób starszych przez instytucje kredytowe i banki szansa na wykreowanie odwróconego kredytu hipotecznego na rynku polskim może być niewielka.

Następnym czynnikiem, który nie będzie sprzyjał rozwojowi omawianego produktu, jest intensywny przyrost form zabezpieczenia emerytalnego, w szczególności form dobrowolnych. Stworzenie produktów adekwatnych do możliwości finansowych przeciętnego Polaka, produktów charakteryzujących się przywilejami podatkowymi, gwarancją uzyskania odpowiedniej stopy zwrotu (np. równej lub wyższej niż stopa inflacji], może spowodować, iż nieruchomość w ogóle nie będzie postrzegana jako element zabezpieczenia emerytalnego. Skorzystanie z dobrze skonstruowanych form długoterminowego oszczędzania w okresie aktywności zawodowej może nie generować potrzeby poszukiwania źródeł dodatkowego dochodu w okresie starości, gdyż taka potrzeba będzie zaspokojona. Wiąże się to istotnie z posiadaną przez społeczeństwo wiedzą finansową ${ }^{37}$. Robert Clark, Melinda Morrill i Steven Allen ${ }^{38}$

34. Szerzej zob. A. Ochocka, Zmiany w „hipotece odwróconej”. Aspekty praktyczne stosowania ustawy o odwróconym kredycie hipotecznym, UKNF, Materiały z seminarium dotyczącego odwróconego kredytu hipotecznego, które odbyło się 11 grudnia $2015 \mathrm{r}$. w siedzibie UKNF.

35. T. Czech, Odwrócony kredyt hipoteczny. Komentarz, Wolters Kluwer, Warszawa 2015.

36. A. Grabowska, Seniorzy jako konsumenci. Wnioski na temat marketingu usług finansowych kierowanych do osób starszych, [w:] Zasada równego traktowania - prawo i praktyka. Osoby starsze na rynku usług finansowych. Analiza i zalecenia, „Biuletyn RPO” 2013, nr 4, s. 26.

37. Czapiński i Góra (2016) w przeprowadzonym badaniu dotyczącym świadomości emerytalnej Polaków, wskazuja na niski jej poziom. Sygnalizują także, Polacy będący w wieku produkcyjnym potrzebują informacji, edukacji emerytalnej oraz istnienia przejrzystych i trwałych zasad funkcjonowania zarówno powszechnego systemu emerytalnego, jak dodatkowych form oszczędzania na emeryturę.

38. R.L. Clark, M.S. Morrill, S. Allen, Pension plan distributions: the importance of financial literacy, [w:] Financial Literacy: Implications for Retirement Security and the Financial Marketplace, [red.] O.S. Mitchell, A. Lusardi, Oxford University Press, Oxford 2011. 
w swoich badaniach wykazuja, iż posiadanie wiedzy z zakresu planowania emerytalnego i rozumienie zasad jego funkcjonowania istotnie wpływa na podejmowanie decyzji finansowych (w zakresie zabezpieczenia emerytalnego) przez osoby fizyczne.

Kolejną determinantą, która z punktu widzenia banków może hamować rozwój odwróconego kredytu hipotecznego, jest ryzyko długowieczności, a w szczególności indywidualne (specyficzne) ryzyko długowieczności (specific longevity risk), polegające na tym, że dana osoba dożyje dłuższego wieku niż oczekiwała. Zatem jeśli przeżyje ona zakładany okres wypłaty świadczeń z odwróconego kredytu hipotecznego, wyczerpując tym samym całą kwotę kapitału zgromadzonego w nieruchomości, spadnie wartość jej dochodów , co spowoduje znaczne obniżenie standardu jej życia, utrudni zaspokojenie ważnych potrzeb życiowych oraz nie pozwoli na utrzymanie nieruchomości w odpowiednim standardzie (nawet niepogorszonym). W konsekwencji doprowadzi do spadku wartości nieruchomości (wskutek braku przeprowadzania regularnych napraw i remontów), co będzie dodatkowym rodzajem ryzyka, które bank będzie musiał ponieść. Dlatego dla banków, które będą oferowały odwrócony kredyt hipoteczny i zawrą znaczną liczbę umów, istotna będzie możliwość skorzystania z instrumentów wspierających zarządzanie ryzykiem długowieczności. Na rynkach rozwiniętych wykształciły się już stosowne instrumenty finansowe, wśród których wyróżnić można: obligacje długowieczności (longevity bonds), survivor swap oraz transakcje forward (tzw. q-forwards) ${ }^{39}$. Implementacja rozwiązań światowych na rynek polski będzie wymagała nie tylko wprowadzenia stosownych regulacji, ale także poniesienia odpowiednich kosztów, aby wdrożone rozwiązania faktycznie pozwalały na skuteczne zarządzanie ryzykiem długowieczności.

Mało zachęcająca dla instytucji oferujących odwrócony kredyt hipoteczny jest możliwość zbycia nieruchomości po roku od momentu śmierci kredytobiorcy (pod warunkiem, że spadkobiercy nie dokonają spłaty kredytu], bowiem realizacja zysku staje się jeszcze bardziej odległa, nie wspominając już o ryzyku spadku wartości nieruchomości w tym czasie. Wspomnieć należy, iż ustawodawca umożliwia także wypłatę jednorazowego świadczenia z odwróconego kredytu hipotecznego. W takiej sytuacji - przy braku odpowiedniego zarządzania przez kredytobiorcę otrzymaną od banku gotówką - zdecydowanie wcześniej może dojść do realizacji ryzyka ceny nieruchomości (a tym samym - do spadku wartości nieruchomości) wskutek braku przeprowadzania bieżących napraw i remontów (choć ustawodawca obliguje do tego kredytobiorcę). Podkreślić trzeba, że odbiorcami odwróconego kredytu hipotecznego są osoby starsze, mogące nie być w stanie same wykonywać nawet drobnych napraw. Sytuacja taka może spowodować, że to właśnie bank będzie musiał w przyszłości ponieść dodatkowe koszty, aby przywrócić odpowiedni stan techniczny nieruchomości, którą będzie chciał spieniężyć, a to istotnie może wpłyną́ na ostateczny zysk banku. Dodatkowo także ustawodawca obliguje kredytobiorcę do ubezpieczenia nieruchomości od zdarzeń losowych, a brak wystarczajacych środków finansowych na zapłatę składki ubezpieczeniowej może doprowadzić do niedoubezpieczenia nieruchomości, co będzie istotnym problemem w momencie zajścia zdarzenia losowego. Dlatego też problematyczna dla

39. Instrumenty te szczegółowo zostały opisane w literaturze przedmiotu, m.in.: D. Blake, A.J. Cairns, K. Dowd, Living with mortality: longevity bonds and other mortality-linked securities, „British Actuarial Journal” 2006, vol. 12, no. 1, s. 153-228; K. Dowd, D. Blake, A.J.G. Cairns, P. Dawson, Survivor swaps, ,The Journal of Risk and Insurance" 2006, vol. 73, no. 1, s. 1-17; G. Coughlan, D. Epstein, A. Sinha, P. Honig, Q-Forwards: Derivatives for Transferring Longevity and Mortality Risk, Pension Advisory Group, JPMorgan, 2007, https://www.researchgate. net/publication/256109844_q-Forwards_Derivatives_for_Transferring_Longevity_and_Mortality_Risks [dostęp: 26.07.2017]. 
banków może być kwestia monitoringu wartości nieruchomości, ale nie tylko w kontekście wzrostu lub spadku cen nieruchomości na rynku, ale każdej z osobna nieruchomości będącej zabezpieczeniem odwróconego kredytu hipotecznego.

Nie bez znaczenia pozostaje także kwestia płynności i wypłacalności banków. Brak stabilnej sytuacji w sektorze bankowym zapewne nie będzie zachęcał osób starszych do współpracy z bankami (zarówno w kontekście deponowania środków, jak i korzystania z odwróconego kredytu hipotecznego).

Czynnikiem, który w dłuższej perspektywie może mieć wpływ na zainteresowanie lub brak zainteresowania omawianym produktem, jest polityka mieszkaniowa. Rozwój różnych form wspierania budownictwa mieszkaniowego przez państwo ${ }^{40}$, może doprowadzić do sytuacji, w której gospodarstwa domowe będa wynajmowały nieruchomości mieszkaniowe, a nie nabywały je na własność. Wówczas liczba nieruchomości, które mogłyby być przedmiotem zabezpieczenia odwróconego kredytu hipotecznego, będzie znacznie mniejsza.

Jednym z ostatnich czynników, o których należy tutaj wspomnieć, jest przywiązanie osób starszych do posiadanej nieruchomości, która niejednokrotnie stanowi dorobek ich życia, a także chęć pozostawienia nieruchomości kolejnym pokoleniom. Nie bez znaczenia pozostaje fakt, iż osoby starsze mogą obawiać się pogorszenia relacji rodzinnych ze spadkobiercami wskutek zawarcia umowy odwróconego kredytu hipotecznego, bowiem pozbawia ono w przyszłości spadkobierców praw do nieruchomości (chyba że dokonają oni spłaty kredytu). Zmiana tej mentalności może być bardzo trudna w polskim społeczeństwie, tym bardziej, że rola rodziny i relacje rodzinne pozostają nadal bardzo ważne. Podejście osób starszych do posiadanej nieruchomości może się zmienić w następnych pokoleniach, ale głównie w tych rodzinach, w których dzieci wyemigrowały (przede wszystkim w celach zarobkowych) i nie będą miały możliwości powrotu, bądź powrót ten będzie bardzo utrudniony (bo np. oznaczał będzie zmianę miejsca pracy i / lub zmianę środowiska życia osób najbliższych). Pozostawione same sobie osoby starsze będące właścicielami nieruchomości moga być bardziej skłonne do korzystania z produktów eqiuty release. Skłonność tę moga pogłębiać problemy zdrowotne i konieczność finansowania opieki zdrowotnej ze środków prywatnych.

\section{Podsumowanie}

Omówione powyżej determinanty rozwoju odwróconego kredytu hipotecznego jednoznacznie wskazują, że włączenie tego produktu na stałe do oferty banków nie jest zadaniem prostym. Obawy tych instytucji wydają się słuszne. Wskazana znaczna liczba barier niestety nie zachęca do wykreowania tego produktu na rynku polskim. Z drugiej jednak strony zmiany demograficzne (przede wszystkich zwiększający się udział osób starszych w społeczeństwie, niekorzystne zmiany struktury gospodarstw domowych) oraz sytuacja finansowa seniorów (malejąca wartość stopy zastapienia w kolejnych latach, niewielka waloryzacja świadczeń emerytalnych) powinny się przyczyniać do zainteresowania tym produktem.

40. Działalność TBS oraz Program Mieszkanie Plus (według wstępnych informacji w programie tym będą dostępne zarówno mieszkania tylko na wynajem, jak i mieszkania z opcją dojścia do własności], szerzej zob. http:// mieszkanieplus.org.pl/ [dostęp: 20.03.2017]. 
Nie bez znaczenia pozostaje także wartość wypłacanych świadczeń z odwróconego kredytu hipotecznego. Ta jednak będzie dopiero znana po wprowadzeniu tego produktu do oferty banków. Jak należy się spodziewać będzie ona zależna od wielu indywidualnych czynników ${ }^{41}$.

\section{Wykaz źródeł}

Barembruch A., Hazard moralny w działalności pośredników finansowych, „Prace i Materiały Wydziału Zarządzania Uniwersytetu Gdańskiego" 2011, nr 4/5.

Bishop T.B, Shan H., Reverse Mortgages: A Closer Look at HECM Loans, 2008, http://www.nber.org/ programs/ag/rrc/08-02\%20Bishop,\%20Shan\%20FINAL.pdf [dostęp: 25.03.2017].

Blake D., Cairns A.J., Dowd K., Living with mortality: longevity bonds and other mortality-linked securities, „British Actuarial Journal” 2006, vol. 12, nr 1.

Caplin A., Inertia in the U.S. Housing Finance Market: Cases and Causes, Paper Prepared for the Joint AEA/AREUEA Session, New York University, New Orleans 2000.

Czapiński J., Panek T., Diagnoza społeczna 2015. Warunki i jakość życia Polaków, Rada Monitoringu Społecznego, Warszawa 2015.

Clark R.L., Morrill M.S., Allen S., Pension plan distributions: the importance of financial literacy, [w: ] Financial Literacy: Implications for Retirement Security and the Financial Marketplace, Mitchell O.S., Lusardi A. [red.], Oxford University Press, Oxford 2011.

Coughlan G., Epstein D., Sinha A., Honig P., Q-Forwards: Derivatives for Transferring Longevity and Mortality Risk, Pension Advisory Group, JPMorgan, 2007, https://www.researchgate.net/ publication/256109844_q-Forwards_Derivatives_for_Transferring_Longevity_and_Mortality_Risks [dostęp: 26.07.2017].

Czapiński J., Góra M., Świadomość „emerytalna” Polaków. Raport z badania ilościowego, Publikacje Europejskiego Kongresu Finansowego, Warszawa 2016.

Czech T., Odwrócony kredyt hipoteczny. Komentarz, Wolters Kluwer, Warszawa 2015.

Dowd K., Blake D., Cairns A.J.G., Dawson P., Survivor swaps, „The Journal of Risk and Insurance” 2006, vol. 73, nr 1.

Equity Release Market Report Spring 2017, http://www.equityreleasecouncil.com/document-library/ equity-release-market-report-spring-201?/ [dostęp: 04.03.2017].

Fornero E., Rossi M.C., Brancati M.C., Explaining why, right or wrong, (Italian) households do not like reverse mortgages, „Journal of Pension Economics and Finance” 2016, 15.

Gibler K., Rabianski J., Elderly Interest in Home Equity Conversion, „Housing Policy Debate” 1993, vol. 4, Issue 4.

Grabowska A., Seniorzy jako konsumenci. Wnioski na temat marketingu usług finansowych kierowanych do osób starszych, [w: ] Zasada równego traktowania - prawo i praktyka. Osoby starsze na rynku usług finansowych. Analiza i zalecenia, „Biuletyn RPO” 2013, nr 4.

41. Pewne oszacowania wartości wypłacanych świadczeń można znaleźć w pracach m.in.: ZBP, Raport: Symulacja możliwości zwiększenia budżetów domowych seniorów przy wykorzystaniu raty kapitałowej odwróconego kredytu hipotecznego dla rożnych rodzajów nieruchomości, Warszawa 2012; P. Kowalczyk-Rólczyńska, T. Rólczyński, Odwrócony kredyt hipoteczny - dodatkowe źródło zabezpieczenia emerytalnego, „Wiadomości Ubezpieczeniowe" 2014, nr 3, s.117-131. 
Grzeszczuk-Gniewek M., Odwrócony kredyt hipoteczny, „Państwo i Społeczeństwo” 2015, nr 2. Gwizdała J.P., Wpływ czynników demograficzno-społecznych na rozwój odwróconego kredytu hipotecznego w Polsce, „Kwartalnik Kolegium Ekonomiczno-Społecznego Studia i Prace” 2015, nr 3, tom 2: Bankowość. Bankowość komercyjna i spółdzielcza.

Joosten A., Equity Release Products. Analysis for the Netherlands, „Netspar Academic Series” 2015, http://arno.uvt.nl/show.cgi?fid=138960 [dostęp: 15.04.2017].

Kłobukowska J., Produkty equity release - szansa czy zagrożenie dla polskich seniorów?, „Pieniądze i Więź" 2013, vol. XVI, nr 1(58).

Komisja Europejska, The 2015 Ageing Report, 2015.

Kowalczyk-Rólczyńska P., Rólczyński T., Odwrócony kredyt hipoteczny - dodatkowe źródło zabezpieczenia emerytalnego, „Wiadomości Ubezpieczeniowe” 2014, nr 3.

Kuchciak I., Odwrócona hipoteka jako odpowiedź sektora bankowego na trendy demograficzne, „Annales Universitatis Mariae Curie-Skłodowska. Sectio H. Oeconomia” 2010, tom 44, nr 2.

Ministerstwo Finansów, Założenia do projektu ustawy o odwróconym kredycie hipotecznym, 2011. Nakajima M., Telyukova I.A., Reverse Mortgage Loans: A quantitative analysis, „Working Paper” 2013, no. 13-27, Research Department, Federal Reserve Bank Of Philadelphia, June 4.

NBP (2016a), Sytuacja finansowa sektora gospodarstw domowych w III kw. 2015 r., Warszawa 2016. NBP (2016b), Raport o stabilności systemu finansowego, Warszawa 2016, http://www.nbp.pl/ systemfinansowy/rsf022016.pdf [dostęp: 10.06.2017].

Ochocka A., Zmiany w „hipotece odwróconej”. Aspekty praktyczne stosowania ustawy o odwróconym kredycie hipotecznym, UKNF, Materiały z seminarium dotyczącego odwróconego kredytu hipotecznego, Warszawa 2015.

Shan H., Reversing the trend: the recent expansion of the reverse mortgage market, „Real Estate Economics" 2011, 39.

TNS Polska, Oszczędzanie długoterminowe - opinie, postawy i oczekiwania polskiego społeczeństwa, 2014, https://zbp.pl/public/repozytorium/wydarzenia/images/listopad_2014/konferencja_prasowa/Raport_2014_11_oszczedzanie_dlugoterminowe_pelny.pdf [dostęp: 08.06.2016]. UKNF (2016a), Indywidualne Konta Emerytalne oraz Indywidualne Konta Zabezpieczenia Emerytalnego w roku 2015, Warszawa 2016.

UKNF (2016b), Informacja dotyczaca pracowniczych programów emerytalnych w 2015 r., https:// www.knf.gov.pl/knf/pl/komponenty/img/informacja_PPE_w_2015_46129_56356.pdf [dostęp: 10.05.2017].

UKNF, Indywidualne Konta Emerytalne oraz Indywidualne Konta Zabezpieczenia Emerytalnego w 2016 roku, Warszawa 201 ?

ZBP, Raport: Symulacja możliwości zwiększenia budżetów domowych seniorów przy wykorzystaniu raty kapitałowej odwróconego kredytu hipotecznego dla rożnych rodzajów nieruchomości, Warszawa 2012.

ZUS, Departament Statystyki i Prognoz Aktuarialnych, Struktura wysokości emerytur i rent wypłacanych przez ZUS po waloryzacji i podwyższeniu świadczeń najniższych w marcu 2017 roku, Warszawa 2017. 


\section{Determinants of development of reverse mortgage on the polish market}

The development of reverse mortgage on the Polish market is conditioned by many factors, which in the literature of the subject are divided into demographic, economic and social. However, among them there are factors which affect the development of reverse mortgage is positive as well as factors that adversely affect the development of this product. In this paper the Author attempts to divide determinants of development of reverse mortgage into two groups: first - factors that inhibit the development of this product, second - factors which stimulate the development of reverse mortgage. Such a division of factors allowed to distinguish these determinants, which constitute a particularly important barrier in the creation of this product on the Polish market.

Keywords: equity release, reverse mortgage, determinants of development, Polish market.

DR PATRYCJA KOWALCZYK-RÓLCZYŃSKA - adiunkt, Uniwersytet Ekonomiczny we Wrocławiu, Katedra Ubezpieczeń 